\title{
Mango Endophyte and Epiphyte Microbiome Composition during Fruit Development and Post-Harvest Stages
}

\author{
Malick Bill, Lizyben Chidamba, Jarishma Keriuscia Gokul (D) and Lise Korsten *
}

Department of Plant and Soil Sciences, University of Pretoria, Hatfield 0028, South Africa; u29280738@tuks.co.za (M.B.); lizbenc@gmail.com (L.C.); jarishma.gokul@up.ac.za (J.K.G.)

* Correspondence: lise.korsten@up.ac.za; Tel.: +27-12-420-3295

Citation: Bill, M.; Chidamba, L.; Gokul, J.K.; Korsten, L. Mango Endophyte and Epiphyte Microbiome Composition during Fruit Development and Post-Harvest Stages. Horticulturae 2021, 7, 495. https: / / doi.org/10.3390/ horticulturae7110495

Received: 15 October 2021 Accepted: 11 November 2021 Published: 15 November 2021

Publisher's Note: MDPI stays neutral with regard to jurisdictional claims in published maps and institutional affiliations.

Copyright: (c) 2021 by the authors. Licensee MDPI, Basel, Switzerland. This article is an open access article distributed under the terms and conditions of the Creative Commons Attribution (CC BY) license (https:// creativecommons.org/licenses/by/ $4.0 /)$.

\begin{abstract}
The influence of the development stage and post-harvest handling on the microbial composition of mango fruit plays a central role in fruit health. Hence, the composition of fungal and bacterial microbiota on the anthoplane, fructoplane, stems and stem-end pulp of mango during fruit development and post-harvest handling were determined using next-generation sequencing of the internal transcribed spacer and 16S rRNA regions. At full bloom, the inflorescence had the richest fungal and bacterial communities. The young developing fruit exhibited lower fungal richness and diversities in comparison to the intermediate and fully developed fruit stages on the fructoplane. At the post-harvest stage, lower fungal and bacterial diversities were observed following prochloraz treatment both on the fructoplane and stem-end pulp. Ascomycota (52.8\%) and Basidiomycota (43.2\%) were the most dominant fungal phyla, while Penicillium, Botryosphaeria, Alternaria and Mucor were detected as the known post-harvest decay-causing fungal genera. The Cyanobacteria (35.6\%), Firmicutes (26.1\%) and Proteobacteria (23.1\%) were the most dominant bacterial phyla. Changes in the presence of Bacillus subtilis following post-harvest interventions such as prochloraz suggested a non-target effect of the fungicide. The present study, therefore, provides the primary baseline data on mango fungal and bacterial diversity and composition, which can be foundational in the development of effective disease (stem-end rot) management strategies.
\end{abstract}

Keywords: pre-harvest; non-target fungicidal effect; phytopathogenic fungi; phytobacteria; plant microbiome; endophyte

\section{Introduction}

The mango (Mangifera indica L.) is a popular fruit mostly due to its delicious taste, attractive fragrance as well as its exceptional flavour and high nutritional value [1]. Depending on the cultivar, growing region and weather conditions, the mango can take 100 to 150 days to reach maturity from the time of flowering (full bloom) to the fully developed fruit [2]. During this period, the fruit is an open ecosystem, able to sustain a diverse microbial population [3] as with many other fruit types [4]. This population is not stagnant and adapts during the developmental growth stages of the fruit from flowering till ready-toeat [5]. These shifts in microbial populations can provide critical windows of opportunity for phytopathogens to colonise the surface and infect the fruit [6]. Natural antagonistic populations can also reside on the surface and have a competitive and/or protective effect within the population dynamics [7]. On the other hand, various commercial practices and interventions may alter the natural developmental stages of a climax and stable microbial community [8].

The understanding of microbial population composition in commercial agricultural production systems presents new opportunities to approach disease control in a more holistic way [9]. To achieve effective disease control on aerial plant sections, a thorough knowledge of the natural microbial population on the affected foliage, flowers and fruit is required [10]. Previously, culture-dependent methods were used to assess microbial 
population dynamics although limitations in depicting the correct microbial community representation were encountered. Furthermore, it could not be ascertained how far the cultured isolates mirrored the indigenous community on the host plant [11]. With the advent of modern next-generation sequencing technologies, the study of total microbial communities and functions has resulted in rapid disease detection and advancements in ecological approaches to disease control [12]. The current popular trend is to study the whole microbial biome of a plant and then unravel the pathogenic component of the population, as well as assess shifts and interactions within the entire microbiome. This level of knowledge on the interaction of economically important pathogens that cause anthracnose and stem-end rot in mango will be beneficial in formulating a more effective pre- and post-harvest disease control strategy.

Several studies have characterised diseases such as stem-end rot [13-15] and anthracnose of mango [16-18] at the pre- and post-harvest stage, assessed the pathogenicity of post-harvest fungal pathogens [19-21] and the efficacy of different post-harvest control strategies of stem-end rot [22-25] and anthracnose [26-32]. To date, microbial dynamics of mango fruit have only been studied at the post-harvest stage [33]. However, to our knowledge, no study has been conducted to investigate microbial population at the pre-harvest stage, a critical period with regards to the establishment of phytopathogens later impacting on ultimate fruit quality. Moreover, the effect of physical and chemical interventions on the natural microbial populations during the mango fruit development growth stages have not yet been probed. Therefore, the purpose of this study was to determine the baseline microbial population of the mango fruit from flowering to ready-to-eat stages. Special emphasis was placed on understanding the microbial composition under commercial growth and production conditions in South Africa and focuses on known pathogenic fungi and potential biocontrol bacteria.

\section{Materials and Methods}

\subsection{Plant Material, Trial Design and Sample Collection}

The experiment was conducted on the mango cultivar Tommy Atkins located in a commercial orchard $\left(23.5792^{\circ} \mathrm{S}, 30.1424^{\circ} \mathrm{E}\right)$ in the Mooketsi valley, Limpopo Province during the 2017/18 growing season. Weather data at the time of sample collection, as well as physical and chemical interventions at different sampling stages, are shown in Table 1. The mango trees (27) were selected in a randomised design within three blocks (nine in each block) with single trees per plot. In order to understand microbial composition at the pre-harvest stage, sampling was carried out at different stages of fruit development, namely full-bloom (whole inflorescence), small $( \pm 129.4 \mathrm{~cm})$, medium $( \pm 197.2 \mathrm{~cm})$ and fully developed $( \pm 271.4 \mathrm{~cm})$ or mature (commercially ready to harvest) fruit for preharvest assessments. A total of 81 samples were collected for each stage of the fruit development and post-harvest stages: per tree, three of each inflorescence, fruitlets or fruit were sampled at the top, middle and lower regions of the tree canopy. To determine postharvest compositions and the effect of post-harvest physical and chemical interventions, comparisons were made between mature fruit harvest (representing day zero in the postharvest context) and samples collected after commercial prochloraz (Chronos ${ }^{\circledR} 45 \mathrm{EC}$, ADAMA, Brackenfell, South Africa) dip treatments, after two weeks of cold storage at $8{ }^{\circ} \mathrm{C}$ and after three weeks cold storage plus seven days at room temperature, representing ripe and ready-to-eat fruit. All the samples were processed within $24 \mathrm{~h}$. 
Table 1. Summary of sampling stages, weather data and physical and chemical interventions during the mango developmental and post-harvest stages.

\begin{tabular}{|c|c|c|c|c|c|c|c|}
\hline \multirow[b]{2}{*}{ Aspect } & \multicolumn{3}{|c|}{ Pre-Harvest } & \multirow{2}{*}{$\begin{array}{c}\text { At Harvest } \\
\text { Mature Fruit }\end{array}$} & \multicolumn{3}{|c|}{ Post-Harvest } \\
\hline & Inflorescence & Small Fruit & Medium Fruit & & $\begin{array}{l}\text { Prochloraz } \\
\text { Dip }^{1}\end{array}$ & $\begin{array}{l}\text { Cold } \\
\text { Storage }\end{array}$ & $\begin{array}{c}\text { Ripe and } \\
\text { Ready-to-Eat }\end{array}$ \\
\hline Time & 0 & 100 days $\mathrm{AFB}^{2}$ & 125 days AFB & 150 days AFB & $\begin{array}{c}2 \mathrm{~h} \\
\text { post-harvest }\end{array}$ & $\begin{array}{c}2 \text { weeks } \\
\text { postharvest }\end{array}$ & $\begin{array}{c}4 \text { weeks } \\
\text { post-harvest }\end{array}$ \\
\hline $\begin{array}{c}\text { Average } \\
\text { temperature }\left({ }^{\circ} \mathrm{C}\right)\end{array}$ & \pm 23 & \pm 28 & \pm 29.5 & \pm 25 & \pm 15 & \pm 8 & \pm 20 \\
\hline $\begin{array}{c}\text { Rainfall (mm) } \\
\text { during sampling }\end{array}$ & $0-10$ & $0-10$ & $10-25$ & $0-10$ & - & - & - \\
\hline $\begin{array}{l}\text { Commercial } \\
\text { intervention or } \\
\text { observations }\end{array}$ & $\begin{array}{l}\text { Insect } \\
\text { activity }\end{array}$ & $\begin{array}{l}\text { Developing } \\
\text { fruit }\end{array}$ & $\begin{array}{l}\text { Copper oxide } \\
\text { spray }^{3}\end{array}$ & $\begin{array}{l}\text { Commercial } \\
\text { harvesting }\end{array}$ & $\begin{array}{l}\text { Post-harvest } \\
\text { handling }\end{array}$ & $\begin{array}{l}\text { Cold storage } \\
\qquad\left(8^{\circ} \mathrm{C}\right)\end{array}$ & $\begin{array}{c}\text { Ripening at room } \\
\text { temperature } \\
\left(20^{\circ} \mathrm{C}\right)\end{array}$ \\
\hline
\end{tabular}

\subsection{Post-Harvest Fruit Quality and Decay Parameters of Mango Fruit}

Physiological maturity parameters for fruit firmness, total soluble solids (TSS) and $\mathrm{pH}$ were measured at harvest, two weeks into cold storage $\left(8^{\circ} \mathrm{C}\right)$ and at the ripe and ready-to-eat mango stage of 10 individually selected fruits representing each sampling stage. Flesh firmness $(\mathrm{kg})$ was determined on two points at the equatorial point of the fruit using a Chitillon Penetrometer, Model DFM50 (Ametek, Largo, FL, USA) according to Woolf et al. [34]. The TSS content (\%) of the fruit was measured according to the method of Nisansala et al. [35] with minor modifications. Total soluble solids were measured from extracted juice using a hand digital refractometer (PR-32, Atago, TSS 0-32\%, Palette, Japan). The fruit $\mathrm{pH}$ was measured according to Montesinos-Herrero et al. [36] with minor modifications, using a Jenway $3510 \mathrm{pH}$ meter (Bibby Scientific Ltd., Stone, UK) with a flat surface electrode combination (Extech Instruments, Waltham, MA, USA). All fruit tested during the study were visually assessed for development of any post-harvest diseases. The disease incidence of stem-end rot and anthracnose was determined as a percentage of decayed fruit in a batch at each evaluation stage.

\subsection{Mango Microbiome Sample Preparation}

\subsubsection{Epiphytic (Fructoplane) Microbiome}

In order to study the epiphytic microflora, $25 \mathrm{~g}$ samples (pre- and post-harvest, $n=7$ ) of inflorescence, fruitlets or fruit were suspended in sterile peptone buffered water $(225 \mathrm{~mL})$ supplemented with $0.025 \%$ Tween 80 (Associated Chemical Enterprises, Johannesburg), and sonicated in an ultrasonic water bath (Labotec, Johannesburg) to dislodge microbes from plant surfaces, as described in Gomba et al. [37]. The micro-floral wash was concentrated by filtration through cellulose nitrate $(0.45 \mu \mathrm{m}$ pore size; Sartorius, Gottingen, Germany) and used for DNA extraction.

\subsubsection{Endophytic (Stem-End Pulp) Microbiome}

The whole fruit, stem-end pulp and fruit stems were sampled to study the endophytic populations of the stem (pre-harvest, $n=3$ ) and internal stem-end (pre- and post-harvest, $n=6$ ) area. All sample types were processed separately according to Diskin et al. [33] and within $24 \mathrm{~h}$ of their collection. Briefly, for the stem-end and stem samples, the fruit and detached (at harvest) fruit stems were surface disinfected with $70 \%$ ethanol for five minutes and then rinsed three times in sterile water for one minute to remove epiphytic microorganisms. The surface disinfected fruit were aseptically peeled at the stem-end with a disinfected peeler. The internal tissue (pulp) of the stem-end portion of the fruit were aseptically removed and cut into smaller pieces using a sterile scalpel blade. The sampled material, i.e., fruit stems (cut into small pieces) and stem-end pulp were immediately snap-frozen in liquid nitrogen and finely ground using a coffee grinder before storage at $-80^{\circ} \mathrm{C}$ for downstream DNA extractions. 


\subsection{DNA Extraction, Amplification and Sequencing}

DNA extraction of the total community was performed on processed flower (anthoplane) and fruit (fructoplane) micro-floral wash, stem-end pulp and stems using the fungal/bacterial Zymo Research kit (ZymoResearch, Irvine, CA, USA), according to the manufacturer's protocol and the extracts stored at $-20{ }^{\circ} \mathrm{C}$. Individual DNA samples $(n=3)$ for each sample type (pre-harvest stage: anthoplane $(n=1)$, fructoplane $(n=3)$ and stem $(n=3)$, stem-end pulp $(n=3)$ and post-harvest stage: fructoplane $(n=3)$ and stem-end pulp $(n=3)$ ) were quantified using the Nanodrop ${ }^{\mathrm{TM}}$ ND2000 spectrophotometer and were thereafter pooled to equivalent concentrations creating 16 individual bulk DNA samples to be used for sequencing.

Bacterial and fungal microbiomes were subjected to paired-end sequencing $(2 \times 300 \mathrm{bp})$ using Illumina MiSeq to target the V4 hyper-variable region of the bacterial $16 \mathrm{~S}$ ribosomal DNA (rDNA) and the internal transcribed spacer region of the fungal 18S rDNA, according to Weisburg et al. [38] and Muyzer et al. [39]. This process involves amplification using bacterial primer set 515F (5'-GTGCCAGCMGCCGCGGTAA-3') and 806R (5'GGACTACHVHHHTWTCTAAT- $3^{\prime}$ ) and fungal ITS1 loci using primers ITS1 (5'-TCCGTAG GTGAACCTGCGG-3') and ITS4 (5'-TCCTCCGCTTATTGATATGC-3'). Raw sequence data are available in fastq format on NCBI-SRA under the BioProject accession number: PRJNA770748.

\subsection{Illumina Sequence Processing and Analysis}

Raw Illumina sequence data were processed using the MR DNA analysis pipeline (www.mrdnalab.com, MR DNA, Shallowater, TX, USA). Sequences were depleted of barcodes and primers and those with ambiguous base calls and $<150$ base pairs in length $[40,41]$ were discarded. Noises, singletons and chimeras were removed from sequences. Thereafter, operational taxonomy units (OTUs) were defined by clustering at a similarity threshold of $97 \%$ using the Usearch algorithm [42]. Generated OTUs were defined by clustering at a similarity threshold of $97 \%$. The OTUs affiliated with Archaea, chloroplast and mitochondria as well as those present at less than $0.1 \%$ abundance were filtered out from the OTU table. Final OTUs were taxonomically classified using BLASTn against a curated database derived from RDPII to NCBI (www.ncbi.nlm.nih.gov, http://rdp. cme.msu.edu) and compiled into each taxonomic level. Non-rarefied sequences were used for $\alpha$-diversity and compositional analysis, while rarefied sequences (at a depth of 1000 sequences) were used to determine $\beta$-diversity. The $\alpha$-diversity of fungal and bacterial communities were calculated using the MicrobiomeAnalyst online pipeline (https://www.microbiomeanalyst.ca/) [43,44].

Two alpha diversity measures were accounted for within this dataset. The ACE (Abundance-based Coverage Estimator) index, a nonparametric method for estimating the number of species using sample coverage, which is defined as the sum of the probabilities of the observed species [45] was used to estimate microbial richness. The Shannon diversity index was able to account for both richness and evenness of the species present in a sample. Statistical differences in beta diversity were inferred with permutational multivariate analysis of variance (PERMANOVA, 999 permutations), using the adonis function in vegan R package. Principal coordinate analyses ( $\mathrm{PCoA}$ ) were performed using the BrayCurtis distance matrix estimation to visualise spatial patterns between samples. Further analysis to quantitatively characterise the composition of agriculturally important taxa was performed via in-depth analysis of the OTU table in Microsoft Excel.

\subsection{Statistical Analysis}

The data were subjected to General Linear Models procedure of Statistical Analysis Systems (SAS) version 9.4 (Institute Inc., Carry, NC, USA) to determine differences in TSS, $\mathrm{pH}$, firmness and disease incidence between sampling stages (harvest to ripe and ready-to-eat stage). 


\section{Results}

\subsection{Physiological Maturity Parameters and Disease Incidence}

Fruit firmness decreased successively during storage, i.e., from at harvest stage to the ripe and ready-to-eat stage ( 1.3 to $0.4 \mathrm{~kg} ; p=0.004)$ while the TSS content ( 14.8 to $20.7 \%$; $p=0.003$ ) and $\mathrm{pH}$ increased (3.8 to 5.9; $p=0.046$ ) (Table 2). Anthracnose was not detected at the pre- or post-harvest stages. Stem-end rot was only detected in ripe and ready-to-eat fruit at $30 \%$ incidence.

Table 2. Physiological maturity parameters and disease incidence of cv. Tommy Atkins mangoes at the post-harvest stages.

\begin{tabular}{cccccc}
\hline Sampling Stage & TSS ${ }^{\mathbf{1}} \mathbf{( \% )}$ & $\mathbf{p H}$ & Firmness (kg) & Anthracnose Incidence (\%) & Stem-End Rot Incidence (\%) \\
\hline At harvest & $14.8 \mathrm{c}{ }^{*}$ & $3.8 \mathrm{c}$ & $1.3 \mathrm{a}$ & $0^{\mathrm{ns}}$ & $0 \mathrm{~b}$ \\
Two weeks in cold storage $\left(8^{\circ} \mathrm{C}\right)$ & $15.9 \mathrm{~b}$ & $4.4 \mathrm{~b}$ & $0.9 \mathrm{~b}$ & 0 & $0 \mathrm{~b}$ \\
Ripe and ready-to-eat & $20.7 \mathrm{a}$ & $5.9 \mathrm{a}$ & $0.4 \mathrm{c}$ & 0 & $30 \mathrm{a}$ \\
\hline
\end{tabular}

${ }^{1}$ TSS, Total soluble solids. ${ }^{*}$, means in the same column with different letters are significantly different $(p<0.05)$.

\subsection{Diversity of Fungal and Bacterial Communities during Different Stages of Mango Production}

A total of 1,458,457 ITS region and 1,119,897 16S region rDNA sequences were recovered from 16 mango fruit developmental and post-harvest handling stages, after paired-end alignments, quality filtering, and deletion of chimeric sequences and singletons. The ITS sequences ranged from 37,464 to 205,514 reads and could be assigned to 4485 fungal OTUs at $97 \%$ similarity, with abundances between 183 and 332 (Table 3). Meanwhile, the $16 \mathrm{~S}$ sequences ranged from 4893 to 114,287 per sample and all could be assigned to 5881 bacterial OTUs at $97 \%$ similarity, with abundances between 239 and 425 (Table 4).

Table 3. Summary of fungal amplicon sequence counts and diversity estimators for mango inflorescence, fructoplane, fruit stem and stem-end pulp at the pre- and post-harvest stages of cv. Tommy Atkins mangoes.

\begin{tabular}{|c|c|c|c|c|c|c|}
\hline \multicolumn{3}{|c|}{ Sampling Stages and Code } & \multirow{2}{*}{ Sequences } & \multirow{2}{*}{ Total OTUs } & \multirow{2}{*}{ ACE } & \multirow{2}{*}{$\begin{array}{c}\text { Shannon (Shannon-Weaver } \\
\text { Diversity Index) }\end{array}$} \\
\hline Stage & Type of Stage & Code $^{1}$ & & & & \\
\hline \multirow[t]{8}{*}{ Pre-harvest } & \multirow[t]{2}{*}{ Inflorescence } & $\mathrm{FP}$ & 73,734 & 183 & 126.9 & 1.76 \\
\hline & & $\mathrm{FP}$ & 98,043 & 250 & 114.3 & 1.32 \\
\hline & \multirow{3}{*}{ Small fruit } & $\mathrm{S}$ & 53,907 & 354 & 83.8 & 1.32 \\
\hline & & SEP & 80,913 & 323 & 91.5 & 1.48 \\
\hline & & $\mathrm{FP}$ & 71,619 & 241 & 115.7 & 1.92 \\
\hline & \multirow[t]{3}{*}{ Medium fruit } & S & 46,462 & 364 & 77.2 & 0.83 \\
\hline & & SEP & 128,211 & 268 & 105.8 & 1.80 \\
\hline & & $\mathrm{FP}$ & 88,454 & 299 & 109.9 & 1.79 \\
\hline \multirow[t]{4}{*}{ At harvest } & \multirow[t]{2}{*}{ Mature fruit } & $\mathrm{S}$ & 37,464 & 315 & 102.7 & 1.83 \\
\hline & & SEP & 90,168 & 289 & 110.8 & 2.39 \\
\hline & After prochloraz & $\mathrm{FP}$ & 60,126 & 245 & 105.5 & 1.19 \\
\hline & packhouse treatment & SEP & 92,011 & 332 & 79.7 & 0.89 \\
\hline \multirow{4}{*}{$\begin{array}{l}\text { Post- } \\
\text { harvest }\end{array}$} & \multirow{2}{*}{ Two weeks cold storage $\left(8^{\circ} \mathrm{C}\right)$} & $\mathrm{FP}$ & 75,921 & 204 & 118.1 & 1.97 \\
\hline & & SEP & 205,514 & 304 & 76.7 & 0.52 \\
\hline & \multirow{2}{*}{ Ready-to-eat stage } & FP & 66,709 & 198 & 122.8 & 2.40 \\
\hline & & SEP & 189,201 & 316 & 81.8 & 0.86 \\
\hline
\end{tabular}

${ }^{1}$ FP, fructoplane; S, fruit stem; SEP, stem-end pulp.

Considering all samples, the epiphytic (anthoplane/fructoplane) fungal and bacterial richness (ACE index) observed at flowering, which is the initial stage of fruit development, was the highest with ACE index-126.9 and 102.6, respectively. Meanwhile, fungal, and bacterial diversities (Shannon index) of 1.76 and 1.19, respectively were recorded at flowering. Assessment of overall richness on the fructoplane revealed the largest fungal (115.7) and bacterial (101.4) richness at the medium size. This corresponded to high fungal (Shannon index, 1.92) and bacterial (Shannon index, 2.32) diversities. When compared to the medium stage, the fungal richness on the fructoplane was low for the small and mature fruit sizes, by $1 \%$ and $5 \%$, respectively. The fungal diversity for the small and mature fruit sizes was 
also low compared to the medium fruit sizes, by $31 \%$ and $8 \%$, respectively. A similar trend was observed with bacterial richness and diversity at these stages of fruit development (Table 3).

Table 4. Summary of bacterial amplicon sequence counts and diversity estimators for mango inflorescence, fructoplane, fruit stem and stem-end pulp at the pre- and post-harvest stages of cv. Tommy Atkins mangoes.

\begin{tabular}{|c|c|c|c|c|c|c|}
\hline \multicolumn{3}{|c|}{ Sampling Stages and Code } & \multirow{2}{*}{ Sequences } & \multirow{2}{*}{ Total OTUs } & \multirow{2}{*}{ ACE } & \multirow{2}{*}{$\begin{array}{c}\text { Shannon-Weaver Diversity } \\
\text { Index }\end{array}$} \\
\hline Stage & Type of Stage & Code $^{1}$ & & & & \\
\hline \multirow[t]{8}{*}{ Pre-harvest } & \multirow[t]{2}{*}{ Inflorescence } & FP & 64,745 & 239 & 102.6 & 1.19 \\
\hline & & FP & 81,349 & 352 & 90.8 & 1.17 \\
\hline & \multirow[t]{3}{*}{ Small fruit } & S & 54,412 & 425 & 100.4 & 1.16 \\
\hline & & SEP & 105,422 & 421 & 97.2 & 2.62 \\
\hline & & $\mathrm{FP}$ & 76,837 & 313 & 101.4 & 2.32 \\
\hline & \multirow[t]{3}{*}{ Medium fruit } & $\mathrm{S}$ & 52,145 & 408 & 83.4 & 1.14 \\
\hline & & SEP & 57,495 & 414 & 83.9 & 1.13 \\
\hline & & $\mathrm{FP}$ & 75,359 & 324 & 98.0 & 1.73 \\
\hline \multirow{4}{*}{ At harvest } & \multirow[t]{2}{*}{ Mature fruit } & $\mathrm{S}$ & 58,768 & 418 & 91.3 & 1.24 \\
\hline & & SEP & 60,271 & 416 & 87.6 & 1.44 \\
\hline & After prochloraz & $\mathrm{FP}$ & 93,785 & 339 & 94.1 & 1.52 \\
\hline & packhouse treatment & SEP & 4893 & 392 & 83.9 & 1.11 \\
\hline \multirow{4}{*}{$\begin{array}{c}\text { Post- } \\
\text { harvest }\end{array}$} & \multirow{2}{*}{ Two weeks cold storage $\left(8^{\circ} \mathrm{C}\right)$} & $\mathrm{FP}$ & 99,451 & 348 & 92.1 & 1.70 \\
\hline & & SEP & 114,287 & 376 & 88.4 & 1.978 \\
\hline & \multirow{2}{*}{ Ready-to-eat stage } & $\mathrm{FP}$ & 51,933 & 314 & 90.6 & 0.76 \\
\hline & & SEP & 68,745 & 382 & 92.4 & 2.27 \\
\hline
\end{tabular}

${ }^{1}$ FP, fructoplane; S, fruit stem; SEP, stem-end pulp.

An analysis of the fruit stems for fungal richness (ACE index) and diversity (Shannon index) (Table 3) showed a decline of $8 \%$ and $37 \%$, respectively from the small fruit to the medium fruit size, while the highest fungal richness and diversity was observed at the fully mature fruit stage. In contrast, the bacterial community, richness and diversity (Table 4) in the fruit stems were highest at the small fruit stage (ACE index: 100.4 and Shannon index: 1.25 ) and decreased by $17 \%$ and $8 \%$, respectively at the medium stage (ACE index: 83.4 and Shannon index: 1.15) but recovered to 91.3 (richness) and 1.18 (diversity) at the mature fruit stage. In stem-end pulp (endophytic) samples, fungal species richness and diversity estimates increased gradually with fruit development and peaked at the mature stage (ACE index: $91.5-110.8$ and Shannon index: $1.48-2.39$, respectively). The stem-end pulp bacterial richness and diversity were highest at the small fruit stage (ACE index: 97.2 and Shannon index: 2.62) and lowest at the medium stage (ACE index: 83.9 and Shannon: 1.13).

Comparisons of fructoplane fungal richness and diversity in response to chemical (prochloraz) showed that the lowest indices (ACE index: 101.4 and Shannon index: 1.19) were recorded after the commercial prochloraz dip treatment, reflecting on an $18 \%$ and $34 \%$ decline, respectively when compared to the untreated fruit (at harvest). Post physical interventions (cold storage), the fungal richness and diversity recovered to ACE index: 118.1 and Shannon index: 1.97 during cold storage and even higher to ACE index: 122.8 and Shannon index: 2.40 at the ripe and ready-to-eat stage (Table 3). The bacterial richness on the fructoplane declined gradually after the prochloraz dip treatment, at the two weeks cold storage stage and at the ripe and ready-to-eat stage (Table 4). In contrast, high fungal richness (ACE index: 110.8) and diversity (Shannon index: 2.39) were recorded in the stem-end pulp area at the point of harvest which sharply declined after prochloraz dip to ACE index: 79.4 and Shannon index: 0.89. At the two weeks cold storage stage, the fungal richness and diversity further declined to 76.3 (ACE index) and 0.52 (Shannon index), respectively but recovered at the ripe and ready-to-eat stage. The stem-end pulp bacterial community richness and diversity followed a similar trend except for an increase in both richness and diversity at the two weeks cold storage stage and further on at the ripe and ready-to-eat stage. 


\section{Beta Diversity}

Evaluation of the PCoA (Figure 1A) ordination showed no distinct clustering patterns in both the fructoplane and stem-end pulp fungal communities at the different developmental stages of mango fruit. PERMANOVA tests $\left(\mathrm{F}=1.09 ; \mathrm{R}^{2}=0.237 ; p=0.357\right)$ also showed no significant effect of sample type (fructoplane and stem-end pulp) at the pre-harvest stage. In fact, a significant effect of sample type $(p<0.05)$ at the post-harvest stage was observed, which was further supported by PERMANOVA testing $\left(F=3.98 ; R^{2}=0.399\right.$; $p=0.026$ ). The fructoplane samples showed discrete clustering while most of the SE pulp samples were broadly scattered across the PCoA (Figure 1B). With regards to bacterial communities, we did not observe a particular pattern between the fructoplane and stemend pulp samples at the pre- and post-harvest stages (Figure 2A,B). This observation was further supported by the PERMANOVA testing $\left(\mathrm{F}=1.02 ; \mathrm{R}^{2}=0.226 ; p=0.373\right)$ which indicated no significant sampling stage effect at the pre-harvest stage. A similar trend was observed with bacterial communities at the post-harvest stage (PERMANOVA testing: $\mathrm{F}=0.761 ; \mathrm{R}^{2}=0.112 ; p=0.639$ ). 

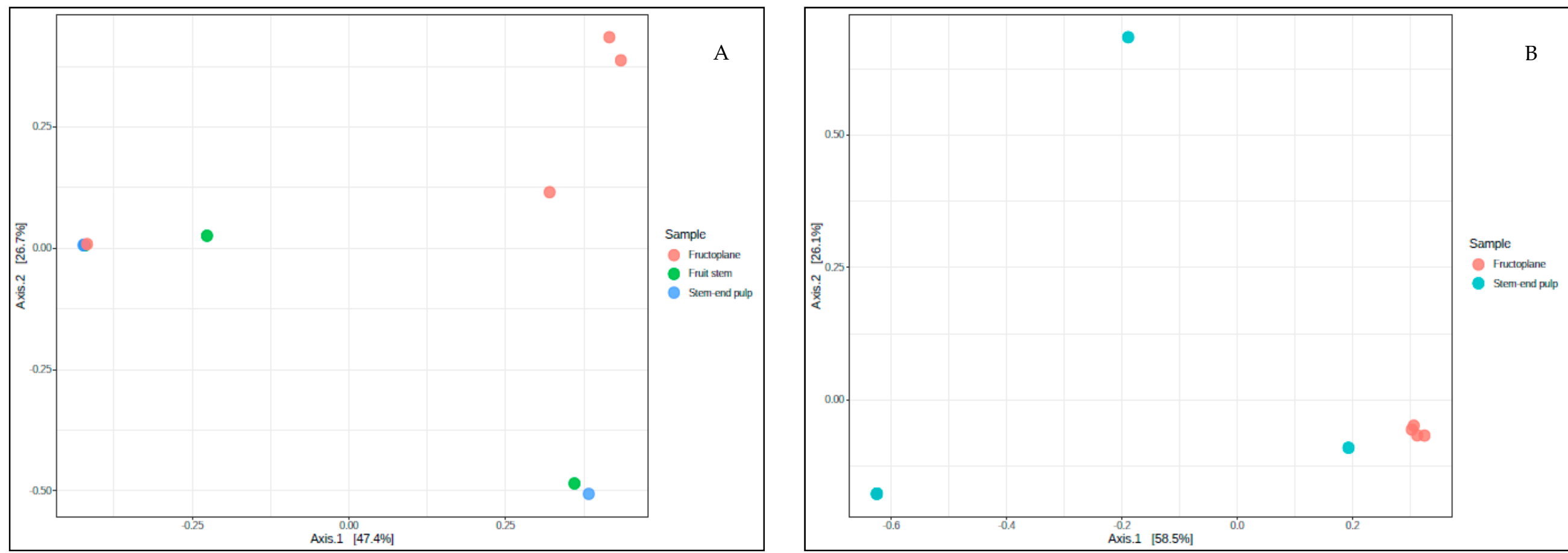

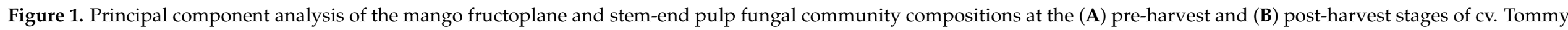
Atkins mangoes, according to Illumina sequencing data. 

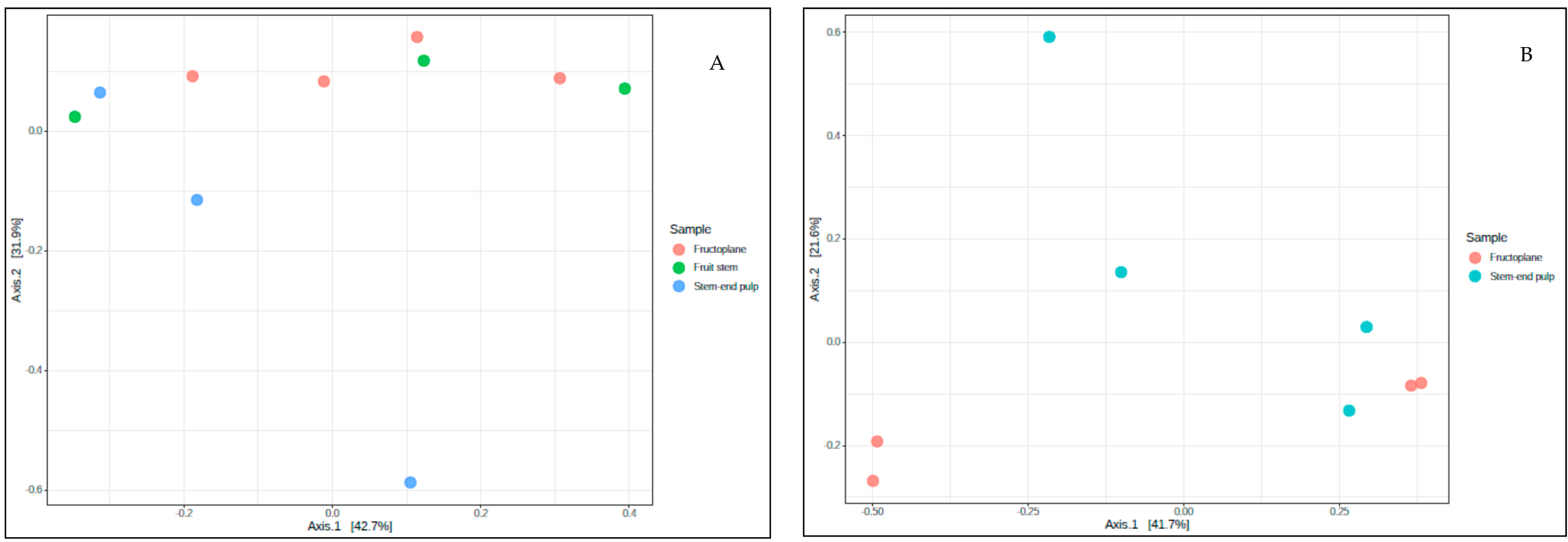

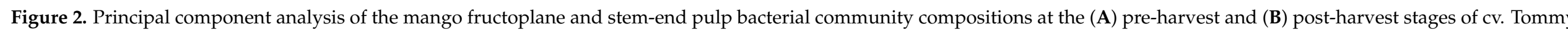
Atkins mangoes, according to Illumina sequencing data. 


\subsection{Structure of Fungal and Bacterial Communities during Different Stages of Mango Production}

The phylum Ascomycota dominated the fungal dataset (52.8\% of total reads) irrespective of sampling stage (Figure 3A,B). Other dominant phyla detected throughout the sampling stages included Basidiomycota (43.2\%) and Mucoromycotina (3.9\%) while Glomeromycota and Entomophthoromycota were detected at $<2 \%$. A total of 85 fungal families were recorded across all the sampling stages of which the Aspergillaceae (31.3\%), Botryosphaeriaceae, (3.7\%), Aureobasidiaceae (2.5\%), Pleosporaceae (1.3\%) and Cladosporiaceae $(0.5 \%)$ dominated the Ascomycota phylum.
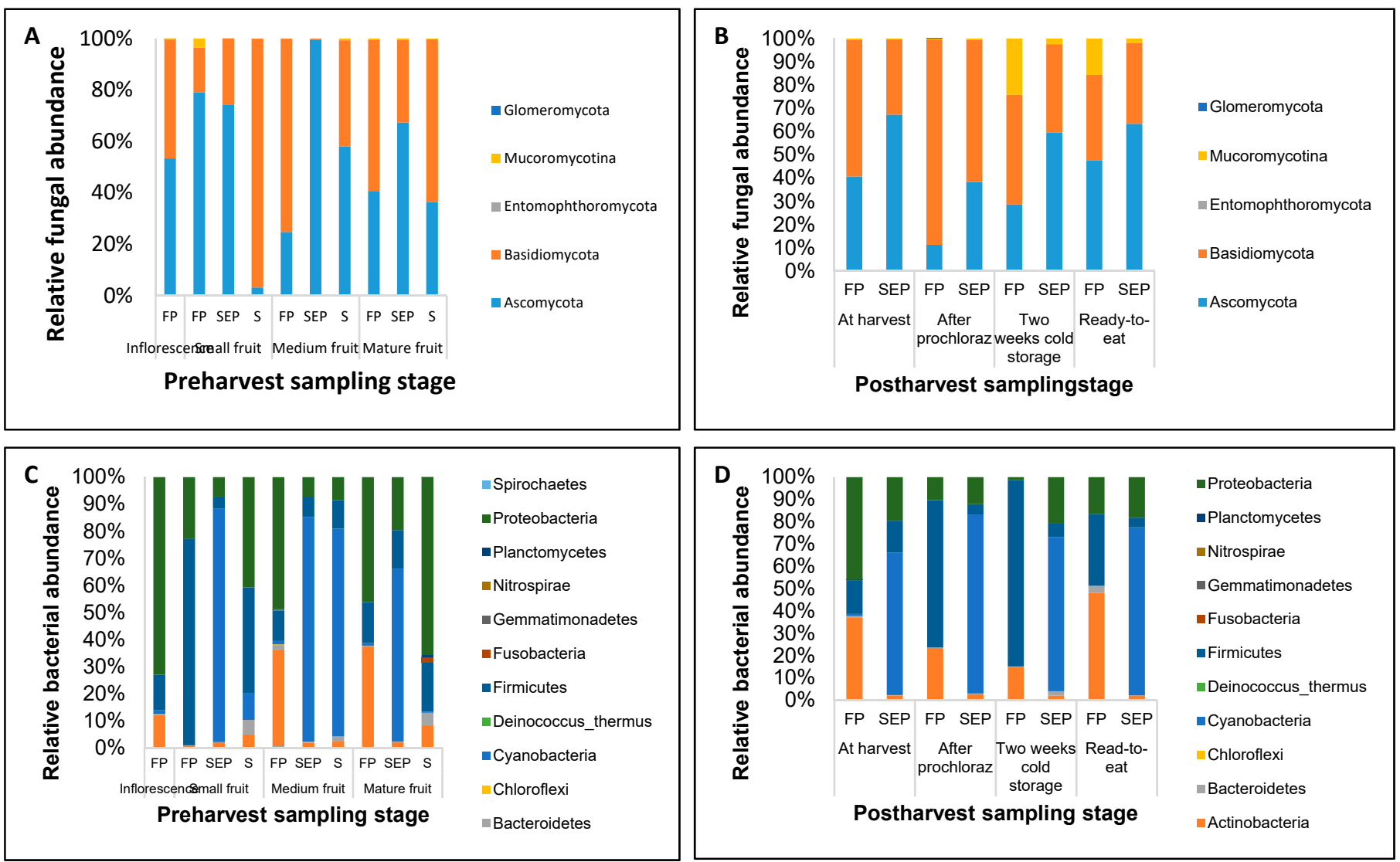

Figure 3. Taxonomic abundance of major fungal phyla on the mango fructoplane, stem-end pulp and fruit stem at the pre-harvest (A) and post-harvest (B) stages; bacterial phyla at the pre-harvest (C) and post-harvest (D) stages of cv. Tommy Atkins mangoes. FP, fructoplane; SEP, stem-end pulp; S, fruit stem.

Mucoraceae (3.9\%), was also detected in substantial abundances both on the fructoplane and in the stem-end pulp area (Figure 4A,B). Of the observed fungal OTUs, 107 OTUs were specific epiphytic (fructoplane) fungi mainly from the families Pleosporaceae, Cladosporiaceae, 45 OTUs were specific endophytic (stem-end pulp) fungi mostly from the families Aspergillaceae and Saccharomycodaceae and 333 OTUs were shared. These included members of Aureobasidiaceae, Dothideomycetes and Filobasidiales among others. 

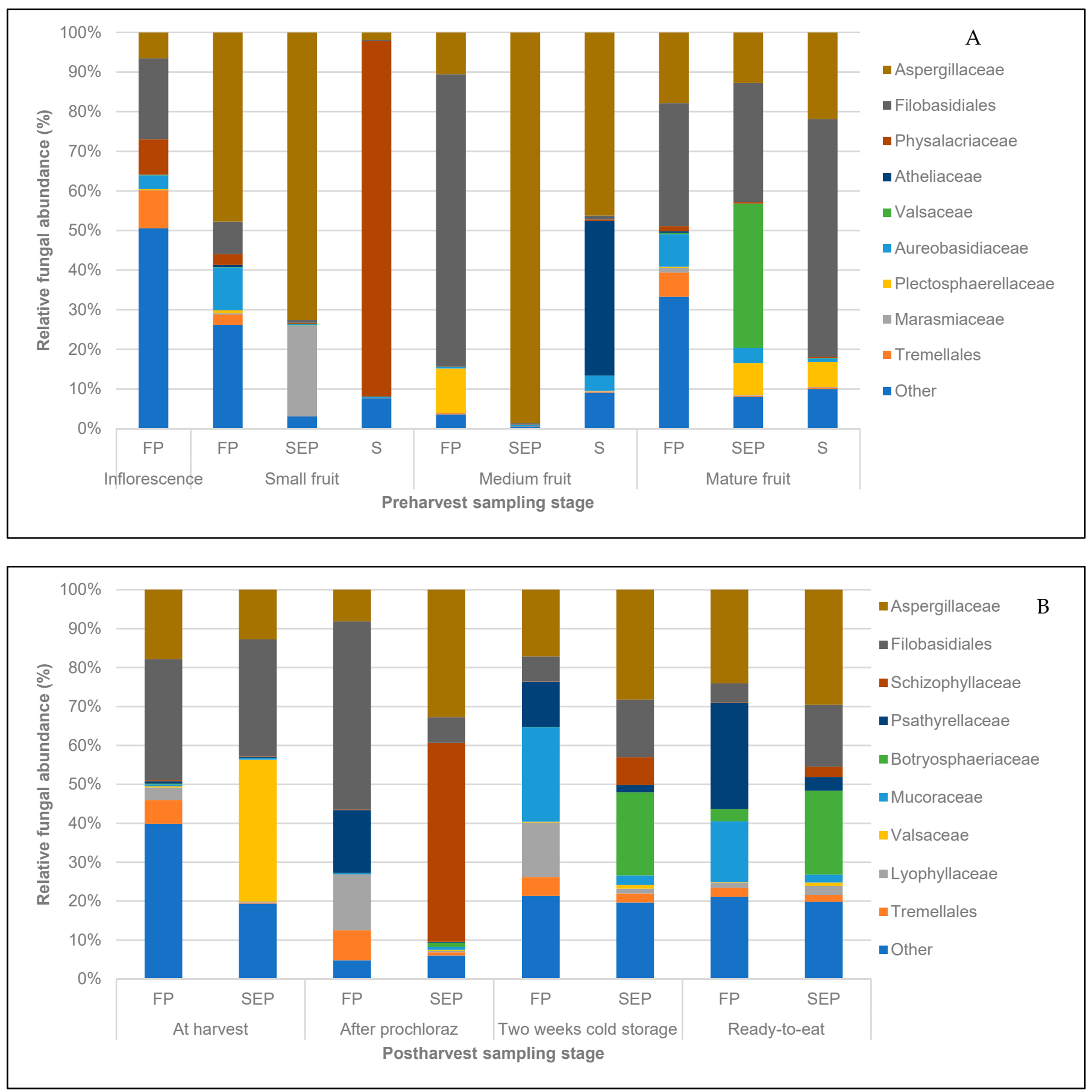

Figure 4. Taxonomic abundance of nine dominant fungal families on the mango fructoplane, stem-end pulp and fruit stem at the pre-harvest (A) and post-harvest (B) stages of cv. Tommy Atkins mangoes. FP, fructoplane; SEP, stem-end pulp; S, fruit stem.

The most dominant bacterial phyla detected throughout the study period included Cyanobacteria (35.6\%), Firmicutes (26.1\%), Proteobacteria $(23.4 \%)$ and Actinobacteria $(14.2 \%)$ (Figure 3C,D). Other phyla included Bacteriodetes, Acidobacteria, Chloroflexi and Gemmatimonadetes, which were present at less than $2 \%$ abundance level. A total of 130 families were found in the bacterial populations, including Staphylococcaceae (12.1\%), Enterobacteriaceae (6.8\%), Bacillaceae (5.0\%), Pseudomonadaceae (2.2\%), Micrococcaceae $(2.2 \%)$, Oxalobacteraceae $(1.3 \%)$, Comamonadaceae $(0.9 \%)$, Sphingomonadaceae $(0.8 \%)$ (Figure $5 \mathrm{~A}, \mathrm{~B})$. Bacterial communities indicated an exclusive epiphytic community of 
49 OTUs including taxa from the Pseudomonadaceae and Microbacteriaceae while the exclusive endophytes consisted of 127 OTUs (e.g., Sphingomonadaceae and Bacillaceae), with 357 OTUs forming the shared community and also included Acetobacteraceae, Bacillaceae, Enterobacteraceae, Micrococcaceae and Pseudomonadaceae among others.
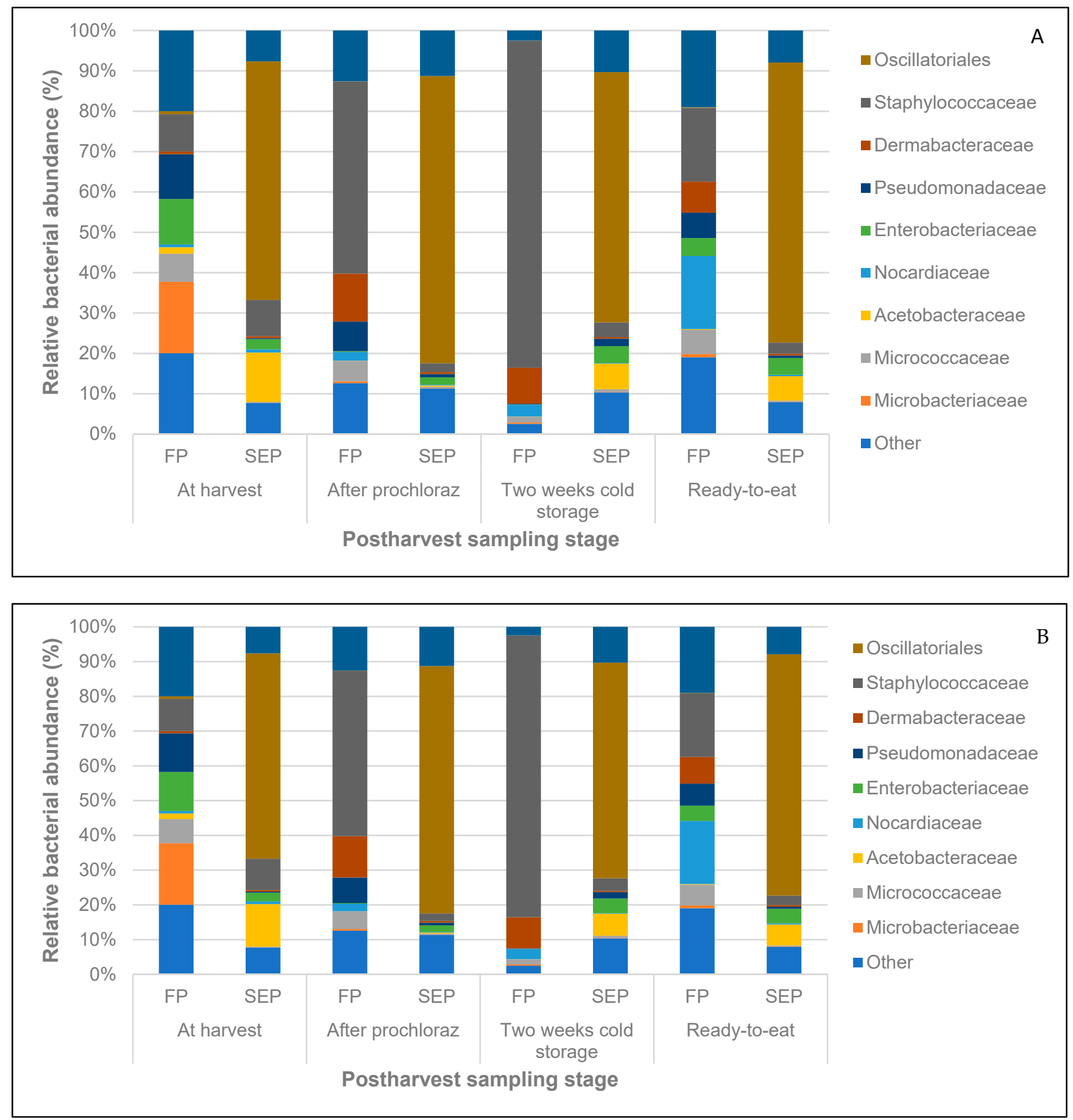

Figure 5. Taxonomic abundance of nine dominant bacterial families on the mango fructoplane, stem-end pulp and fruit stem at the pre-harvest (A) and post-harvest (B) stages of cv. Tommy Atkins mangoes. FP, fructoplane; SEP, stem-end pulp; $\mathrm{S}$, fruit stem. 


\subsection{Identification of Pathogenic Fungal Taxa at the Pre- and Post-harvest Stages of Mango}

In-depth analysis of the OTU tables permitted the identification of commercially significant microbes for their pathogenic and beneficial importance (Table 5, Figure S1A,B). Eight pathogenic fungal genera were present at both the pre- and post-harvest stages (Table 5) and included genera associated with stem-end rot: Botryosphaeria, Cladosporium, Aspergillus, Penicillium and Alternaria. Other fungal pathogens detected were Phoma, Mucor and Fusarium. On the fructoplane, the genus Penicillium was detected at all stages of fruit development, with abundances ranging from $10.6 \%$ to $47.7 \%$, and peaking at the small fruit stage (Penicillium commune Thom. - 0.49\%) (Table 5 and Figure S1A). Sequences belonging to the Alternaria genus (Alternaria alternata (Fr.) Keissl.) were also detected in all the samples, with the highest abundance of Alternaria observed on the fructoplane of small fruit (5.5\%) and lowest on medium-sized fruit (0.17\%). Botryosphaeria dothidea (Moug. Ex Fr.) Ces. and De Not. $(<0.2 \%)$ and Cladosporium cladosporioides (Fres.) de Vries $(0.3 \%)$ sequences were the least abundant on the fructoplane throughout fruit development, while Fusarium detected on the fructoplane showed a gradual decline from the small to the fully mature stage ( $1.3 \%$ and $0.8 \%$ respectively). The highest abundance of the Phoma (2.3\%) and Mucor (3.6\%) genera on the fructoplane was observed at the small fruit stage and declined substantially at the medium to fully mature fruit stages. The Mucor genus was generally dominated by two pathogenic species Mucor circinelloides and Mucor racemosus (Figure S1A).

The fruit stems were also dominated by Penicillium genus sequences throughout fruit development, ranging from $1.9 \%$ to $42.6 \%$. Penicillium commune (Figure S1A) was the most dominant in the fruit stems of small $(72.3 \%)$ and medium $(98.5 \%)$ sized fruit, remaining the most dominant $(12.5 \%)$ on mature stage fruit. Most of the stem-end rot genera were present at abundances lower than $2 \%$ in all three stages of fruit development except for Botryosphaeria and Aspergillus sequences that could not be detected during the first two stages of fruit development. Sequences of the Penicillium genus also dominated the stem-end pulp, increasing from $72.6 \%$ at the small fruit stage to $98.6 \%$ at the medium development stage. On the contrary, the presence of P. commune in the stem-end pulp decreased from $45.4 \%$ at small to $10.5 \%$ at medium fruit stages. The remainder of the stemend rot and pathogenic species had prevalences under $0.3 \%$ during fruit development.

Botryosphaeria, Cladosporium, Aspergillus, Penicillium and Alternaria on the fructoplane responded to chemical and physical post-harvest interventions stages, showing a distinct decline in relative abundance (Table 5). The most remarkable of these were for Penicillium and Alternaria demonstrating decreases of $54.22 \%$ and $82.95 \%$ in relative abundance respectively following the prochloraz dip treatment. The Penicillium genus was detected on all the samples on the fructoplane at the post-harvest stage with the highest abundance at the ripe and ready-to-eat stage $(24.0 \%)$. However, the proportion of P. commune increased from $5.5 \%$ at harvest to $46.0 \%$ after prochloraz dip treatment, followed by a gradual decline at two weeks cold storage to $29.2 \%$ and ripe and ready-to-eat stage to $27.1 \%$ (Figure S1B). Despite being present in very low abundances $(0.16 \%)$ at harvest and abundance declining after prochloraz treatment to $0.02 \%$, sequences of the Botryosphaeria (specifically B. dothidea) genus increased dramatically to $3.1 \%$ at the ripe and ready-to-eat stages on the fructoplane. As for the stem-end pulp, the Penicillium genus was detected in the highest abundances $(30.6 \%)$ after prochloraz dip followed by a $7.7 \%$ decline at two weeks of cold storage. Botryosphaeria in the stem-end pulp showed the highest (21.6\%) abundances at the ripe and ready-to-eat stage after a sharp increase after the prochloraz dip $(0.7 \%)$. The abundance of the Mucor genus increased similarly after the prochloraz treatment $(0.7 \%)$ at the ripe and ready-to-eat stage $(2.0 \%)$. However, despite the observed increase in the sequences of the Mucor genus, its dominant members, Mucor circinelloides Tiegh. and Mucor racemosus Bull. remained the least dominant $(0.2 \%)$ in the stem-end pulp at the ready-to-eat stage. 
Table 5. Genera of pathogenic and beneficial microorganisms detected in cv. Tommy Atkins mangoes sequence profile.

\begin{tabular}{|c|c|c|c|c|c|c|c|c|c|c|c|c|c|c|c|c|}
\hline \multirow{3}{*}{$\begin{array}{l}\text { Sampling } \\
\text { Stage }\end{array}$} & \multicolumn{7}{|c|}{ Pre-Harvest } & \multirow{2}{*}{\multicolumn{3}{|c|}{$\begin{array}{c}\text { At Harvest } \\
\text { Mature Fruit: Point of Harvest }\end{array}$}} & \multicolumn{6}{|c|}{ Post-Harvest } \\
\hline & \multirow{2}{*}{$\begin{array}{c}\text { InfloRescence } \\
\text { FP }^{1} \\
\end{array}$} & \multicolumn{3}{|c|}{ Small Fruit } & \multicolumn{3}{|c|}{ Medium Fruit } & & & & \multicolumn{2}{|c|}{ After Prochloraz Dip } & \multicolumn{2}{|c|}{ Two Weeks Cold in Storage $\left(8^{\circ} \mathrm{C}\right)$} & \multicolumn{2}{|c|}{ Ripe and Ready-to-Eat } \\
\hline & & FP & $\mathrm{s}$ & SEP & FP & $\mathrm{s}$ & SEP & FP & $\mathbf{s}$ & SEP & FP & SEP & $\mathbf{F P}$ & SEP & FP & SEP \\
\hline \multicolumn{17}{|c|}{ Stem-end rot causing fungi (\%) } \\
\hline Botryosphaeria & 0.43 & 0.63 & - & 0.01 & 0.01 & - & 0.01 & 0.16 & 0.16 & 0.02 & 0.02 & 0.74 & 0.10 & 21.37 & 3.13 & 21.57 \\
\hline Cladosporium & 1.04 & 0.83 & 0.01 & 0.04 & 0.11 & - & 0.02 & 1.13 & 0.08 & 0.10 & 0.04 & 0.13 & 0.34 & - & 0.12 & - \\
\hline Aspergillus & - & 0.10 & - & - & 0.01 & - & 0.02 & - & - & - & - & 2.22 & 0.02 & - & 0.01 & - \\
\hline Penicillium & 6.53 & 47.65 & 1.87 & 72.61 & 10.56 & 46.24 & 98.61 & 17.85 & 1.87 & 12.78 & 8.17 & 30.55 & 17.16 & 28.21 & 24.04 & 29.59 \\
\hline Alternaria & 1.13 & 5.53 & - & 0.01 & 0.17 & 0.09 & 0.06 & 4.34 & 0.08 & 0.07 & 0.74 & 0.13 & - & 0.12 & 0.10 & - \\
\hline Colletotrichum & - & - & - & - & - & - & & - & & - & - & - & - & - & - & - \\
\hline Phoma & 7.79 & 2.29 & 0.01 & - & 0.02 & 0.05 & 0.05 & 0.48 & 0.11 & 0.02 & 0.04 & 0.20 & 0.29 & 0.49 & 0.29 & 0.15 \\
\hline Mucor & 0.39 & 3.55 & 0.09 & 0.08 & 0.10 & 0.09 & 0.09 & 0.48 & 0.27 & 0.43 & 0.33 & 0.74 & 24.25 & 2.44 & 15.67 & 2.04 \\
\hline Fusarium & 0.43 & 1.25 & 0.05 & 0.04 & 1.18 & 0.05 & 0.01 & 0.80 & 1.37 & 0.48 & 0.02 & 0.20 & 1.22 & 0.37 & 2.61 & 1.17 \\
\hline \multicolumn{17}{|c|}{ Beneficial bacteria (\%) } \\
\hline Bacillus & 1.23 & 66.49 & 0.47 & 0.79 & 1.11 & 0.98 & 0.93 & 1.87 & 0.31 & 1.78 & 0.76 & 0.37 & 0.20 & 0.75 & 2.33 & 0.66 \\
\hline Bacillus subtilis & 0.06 & 0.04 & 0.22 & 0.13 & - & 0.09 & 0.25 & 0.15 & 0.07 & 0.15 & 0.04 & 0.03 & 0.01 & 0.12 & 0.02 & 0.13 \\
\hline Lactobacillus & 0.62 & 0.01 & - & - & 0.08 & - & - & - & - & 0.02 & - & - & - & - & - & 0.03 \\
\hline
\end{tabular}

${ }^{1}$ FP, fructoplane; S, fruit stem; SEP, stem-end pulp. 


\subsection{Beneficial Bacterial Taxa Present at the Pre-and Post-Harvest Stages of Mango}

The $16 \mathrm{~S}$ amplicon sequences of the Bacillus genus were detected at an overall abundance of $6.1 \%$ throughout all the sampling stages (Table 5). A low abundance (1.2\%) of Bacillus was observed on the inflorescence. Bacillus subtilis was also detected in much lower abundances $(0.1 \%)$ at this stage. The Bacillus genus was more prevalent at the small fruit stage during pre-harvest $(66.5 \%)$, which was followed by a very sharp decline to $1.1 \%$ at the medium fruit development stage where B. subtilis could not be detected (Table 5). Meanwhile, the presence of Bacillus (1.9\%) on the fructoplane at the mature fruit stage resulted in a $0.15 \%$ increment in B. subtilis prevalence. Fruit stems at the small fruit sampling stage were also characterised by a very low presence $(0.5 \%)$ of Bacillus and $1 \%$ relative abundance at the medium fruit size, which subsequently declined to $0.3 \%$ at the mature stage. Stem-end samples had one of the lowest presences of Bacillus $(0.8 \%)$ at the small fruit stage but were present at slightly higher abundance $(1.8 \%)$ at the mature stage and B. subtilis followed a similar trend except for the low presence at the mature stage.

The abundance of the Bacillus genus on the fructoplane declined to $0.8 \%$ after prochloraz dip treatment compared to that of mature fruit at harvest $(0.8 \%)$ (Table 5). A further $10 \%$ decline in the abundance of Bacillus at two weeks cold storage and a 10-fold increment at the ripe and ready-to-eat stage to $2.3 \%$. Bacillus subtilis also followed the same trend. Further, $B$. subtilis was present at all post-harvest stages in the stem-end pulp with a decline observed after prochloraz dip and during cold storage. Lactobacillus was only detected at continuously decreasing low relative abundance on the fructoplane from inflorescence to medium fruit size $(0.01-0.62 \%)$ and in the stem end pulp of mature fruit $(0.02)$.

\section{Discussion}

\subsection{Microbial Diversity and Composition at the Pre- and Post-Harvest Stages of Mango}

The dynamics of the microbial community of fresh produce have blossomed in the last decade, with a focus on establishing the factors that contribute to shifts or changes in the microbiota. The present study highlighted a change in diversity and composition of bacterial and fungal amplicon-based marker genes associated with various stages of mango growth and post-harvest value chain (anthoplane, fructoplane, fruit stems and stem-end pulp).

As reproductive structures, flowers are essential to the propagation success of plants and provide the first platform for microbial fructoplane succession. Understanding the microbial inhabitants in this ecologically important zone plays a key role in the health and reproductive success of plants [46]. The study revealed a rich fungal community on the anthoplane at the full bloom stage. The majority $(80 \%)$ of the fungal families (85) detected were present on the anthoplane of the mango inflorescence; most were members of the Ascomycota phylum of which Pleosporaceae (Alternaria), Cladosporiaceae (Cladosporium), and Didymellaceae (Phoma.) have previously been detected on mango flowers using culture-dependent methods as the most dominant inflorescence fungi [3]. Other previously detected fungi species which were present on the mango inflorescence in our study included Mucoraceae (Mucor), Nectriaceae (Fusarium), Botryosphaeriaceae (Botryosphaeria) and Aspergillaceae (Penicillium). The most dominant bacterial phyla observed on the inflorescence were Cyanobacteria, Firmicutes, Proteobacteria and Actinobacteria. Proteobacteria (Enterobacteriaceae), Firmicutes (Bacillus) and Actinobacteria (Actinobacterium, Curtobacterium, Microbacterium) have previously been reported to dominate the flowers of grapes, tomato and apple $[4,47,48]$. Most of the bacterial families previously reported to harbour the mango fructoplane including Staphylococcaceae, Enterobacteriaceae, Bacillaceae, Pseudomonadaceae, Micrococcaceae, Oxalobacteraceae, Comamonadaceae, Sphingomonadaceae [33] were also detected on the inflorescence in the current study.

Flowers at the full bloom stage attract a diverse range of floral visitors including pollinating and non-pollinating insects that may transfer microbial organisms to the flower [49], thus enhancing microbial richness when compared to other developmental phases such as fruit-set and mature fruit stages [50]. The high level of sugars and certain nutrients further 
contributes to the establishment of a rich microflora [3]. Once established, the diverse microflora may be sustained by the continuous provision of nectar and exudates [51] providing a rich nutrient base for colonisation.

The transition of flowers into young fruits (small size stage) was associated with a decline in fungal diversity in the stem-end pulp. The present study further revealed that, in the stem-end pulp, fungal richness and diversity were lowest at the small size fruit stage. This could be a result of low sugar content in the pulp of immature mango fruit, which increases gradually as the fruit develops [52]. It was also observed that the fungal richness and diversity in fruit stems and stem-end pulp climaxed at the mature fruit stage whereas that of the fructoplane peaked at the small fruit stage. The peak fungal diversity for each sample type (fruit stem, stem-end pulp and fructoplane) correlated with the low abundance of the Penicillium genus. Furthermore, the fruit stem harboured a less diverse community compared to the stem-end pulp across all stages of fruit development. Generally, the Ascomycota and Basidiomycota phyla have been reported to dominate fruit fungal profiles $[50,53]$, including the flowering stage in apple, pear and fig $[47,54,55]$ as previously mentioned. Similar observations were made in the current study, as well as the presence of other fungal phyla such as Mucoromycotina and Entomophthoromycota, previously not reported as prevalent on mango. Penicillium commune was the most dominant fungal species detected on the mango fructoplane with the most $(21.7 \%)$ number of OTUs at medium fruit development stage $(21.7 \%)$. The fungal community structure of mango fruit at the post-harvest stage was also reported to change during storage [33]. Immediately after post-harvest treatment, pesticide concentrations will be higher on the fruit surface but will gradually decline as the product breaks down or diffuses into the fruit [56], which explains surface population and endophyte recovery in endophytic Botryosphaeria at two weeks cold storage.

A study on the microbial ecology of the grapevine found high diversity in epiphytic (fructoplane) populations compared to endophyte (stem-end pulp) populations [57], similar to the present study. Differences in fungal diversity were also noted on the fructoplane between three different fruit developmental stages. This study revealed higher fungal diversity on the fructoplane in immature (small and medium fruit stages) mango fruit (114.3 and 115.7) compared to fully mature fruit (109.9), an observation that was in contrast to that in bananas, another tropical fruit [58]. The low fungal diversity in mature fruit could be ascribed to several factors including a decrease in available nutrient levels [10] and unfavourable environmental conditions such as higher temperature, low relative humidity and dry periods [59]. In addition, during fruit development, various physiological and biochemical changes take place [60], that can affect the diversity of the fungal communities inhabiting the fruit. Noticeable differences in the morphological features (wax development) of the mango surface also take place between immature and mature fruit [61].

The observed differences in fungal diversity could also be due to management practices [62] during fruit development. A decrease in microbiome diversity was observed in subtropical fruit when sprayed with copper [63]. In commercial mango orchards in South Africa, copper is sprayed during fruit development until 14 days before harvest, at 28-day intervals under dry conditions or 14- to 21-day intervals under rainy conditions. The application of copper sprays could, therefore, have resulted in a decline in the abundance of pathogenic fungi [64] and other non-target organisms, creating a microbial vacuum [65].

Further to this, fungicide applications are known to affect microbial balance and diversity on mango fruit [3]. The commercial application of prochloraz dip treatment to post-harvest mangoes was associated with a decline in both fungal and bacterial diversities on both the fructoplane and stem-end pulp area. The effect of prochloraz was also visible on the fungal beta diversity in the stem-end pulp which resulted in these communities clustering far apart from the rest. Prochloraz is known to target several fungal groups by inhibition of ergosterol, a fatty acid that is vital to the structural formation of fungal cell membranes [66]. Despite prochloraz being non-systemic, there is a possibility of fungicide 
internalisation [67] into the stem-end area during commercial dipping, potentially resulting in a decline in fungal diversity in this area. To date, the direct effect of copper sprays over time (pre-harvest), as well as the non-target effect of prochloraz (post-harvest) on microbial diversity has not been reported and warrants future investigation.

For mangoes exposed to cold storage until the ripe and ready-to-eat stage, fungal stem-end pulp communities and bacterial stem-end pulp communities showed indications of recovery post prochloraz dip. The increase in both the fungal and bacterial diversities at the ripe and ready-to-eat stage in the stem-end pulp could have been due to the combined effect of an increase in the availability of sugars (total soluble solids) and a decrease in $\mathrm{pH}$ level as the fruit ripened [33]. This, therefore, created an environment that is characterised by less competition for food and more diverse fungal populations [68].

\subsection{Pathogenic Fungal Taxa Composition at the Pre-and Post-Harvest Stages of Mango}

During flowering typical stem-end pathogens get introduced [69], often via infection through the stamen, as was reported with Alternaria alternata for citrus [70]. Well-known stem-end pathogens, e.g., Dothiorella (avocado) and Botryosphaeria (mango) remain in this area as endophytes and typically move into the stem-end area of the fruit during maturation. The resultant development of stem-end rot represents a significant post-harvest disease in mango [64].

The presence of pathogenic signatures during fruit development and at the postharvest stage in response to physical and chemical interventions was evaluated based on the observed abundance of OTUs belonging to fungi responsible for post-harvest diseases of mango fruit. This included Penicillium, Alternaria, Botryosphaeria, and Fusarium [71].

Penicillium digitatum was reported as the only known stem-end pathogen in mango belonging to the Penicillium genus [72], however, we did not detect it in the present study. Penicillium commune was detected as an endophyte in fruit stems and showed a presence at all stages of fruit development. The lowest relative abundance of $P$. commune in the fruit stems at the mature stage coincided with a $61 \%$ increase in abundance in the stem-end pulp. P. commune was previously reported as a fungal endophyte isolated from avocado roots [73]. To date, there are no reports on the pathogenicity of P. commune in mango. However, the fungus was reported as pathogenic to pears and apples [74,75].

Mucor racemosus Bull. a prevalent member of the Mucoraceae family, was reported to be pathogenic to cherry tomato (Soft rot) and mandarin (Mucor rot) [76,77] and has previously been detected on mango flowers [3]. However, there were no reports of $M$. racemosus being pathogenic to mango. In this study, M. racemosus was detected in post-harvest mangoes, and at relatively high abundances at the small fruit stage which declined as the fruit developed. However, despite the observed increase in the sequences of the Mucor genus, its dominant members, Mucor circinelloides Tiegh. and Mucor racemosus remained the least dominant $(0.2 \%)$ in the stem-end pulp at the ready-to-eat stage.

The family Botryosphaeriaceae is composed of many pathogenic members [78] including B. dothidea, a common causal agent of stem-end rot in mango; [79] reported that, $B$. dothidea grows endophytically in mango pedicels during fruit development and spreads into fruit a few weeks before they reach harvest maturity to form quiescent infections. This genus was detected in the present study and observed to have a relative abundance in the stem-end pulp at the mature fruit stage two times as high as that of the medium stage. Botryosphaeria dothidea was generally detected in very low abundances on the fructoplane $(<0.2 \%)$ at the pre-harvest stage, which is in agreement with [79] who reported that $B$. dothidea grows endophytically in mango pedicels during fruit development and spreads into fruit a few weeks before they reach harvest maturity to form quiescent infections. Furthermore, the detection of B. dothidea at the inflorescence stage $(0.09 \%)$ and almost non-detection in fruit stems and stem-end pulp at the small and medium fruit stages in this study confirm that a critical infection period exists during flowering [70].

Alternaria alternata, a member of the Pleosporaceae family was previously reported to be the most abundant pathogen in semi-dry arid areas and the most important mango 
pathogen in countries such as Israel [80]. Alternaria signatures were detected on the mango fructoplane in all development stages. Alternaria, Cladosporium and Botryosphaeria signatures did, however, demonstrate their lowest abundances at the medium fruit stage which could be attributed to low nutrient levels. According to Blakeman [10], this is a result of morphological changes on the fruit surface which occur during fruit development in mango [61]. Further to this, it is essential to keep in mind that a commercial copper spray was applied to the orchard a week prior to sampling during the medium fruit stage. Since the non-target effect of commercial copper sprays on the presence of fungi is well known [63], this once again raises the need for extensive assessments on the effect of copper sprays as a biocontrol agent on microbial biomes of mango.

At the post-harvest stage, the ability of prochloraz to control a diverse range of fungal genera common to mango including Gloeosporium, Penicillium, Alternaría, Botrytis, Fusarium, Phoma, Sclerotinia and Colletotrichum was the subject of extensive research on avocados [66]. The findings of the present study revealed that most of the families including Aspergillaceae (Penicillium), Aureobasidiaceae, Pleosporaceae (Alternaria), Cladosporiaceae (Cladosporium) and Botryosphaeriaceae (Botryosphaeria) declined following prochloraz dip treatment. The exception was P. commune, which indicated that prochloraz had no effect on their relative abundance, which was 2.4 times higher than at the harvest stage fruit. Usually, this organism is known to rapidly colonise a niche once other competing organisms are removed, representing a typical strategist [81]. Interestingly, the Penicillium genus showed a stark inversely proportional relationship between the $P$. commune and other species present. The fungal community structure of mango fruit at the post-harvest stage was also reported to change during storage [33]. Immediately after post-harvest treatment, pesticide concentrations will be higher on the fruit surface but will gradually decline as the product breaks down or diffuses into the fruit [56], which explains surface population and endophyte recovery in endophytic Botryosphaeria at two weeks cold storage.

Further on, Alkan and Fortes [60] indicated that during the ripening process, fruits exhibit biochemical and physiological changes that include a decrease in important defence mechanisms such as phytoanticipin, phytoalexin levels, inducible plant defence mechanisms, and changes in ambient host $\mathrm{pH}$. The decline in the defence mechanisms as the fruit ripens results in an increase in pathogenic members of the Ploeosporace and Davidiallaceae families in the stem-end [33]. Over the course of this study, we observed that the abundance of $A$. alternata was undetected at the ready-to-eat stage, whereas $B$. dominica, one of the least abundant fungi at the pre-harvest stage, was detected in high relative abundances (21\%) in the stem-end pulp at the ripe and ready-to-eat stage. More so, the high occurrence of $B$. dominica during pre-harvest resulted in a higher stem-end rot occurrence in mango [64], hence the $30 \%$ incidence observed at the ready-to-eat stage. In addition, Mucor racemosus a prevalent member of the Mucoraceae family was also detected in relatively high abundances in the stem-end at the post-harvest stages. The fungus was reported to be pathogenic to cherry tomato (Soft rot) and mandarin (Mucor rot) [76,77]. To date, there are no reports on $M$. racemosus being pathogenic to mango and its elevated presence on the fruit surface and the stem-end pulp at the post-harvest stage is of concern. Future work should focus on assessing the pathogenic potential of such organisms prevalent in mango fruit.

\subsection{Beneficial Bacterial Taxa Composition at the Pre-and Post-Harvest Stages of Mangoes}

Bacillaceae, a family of interest in plant health [82] play fundamental roles in soil ecology, plant health and growth stimulation via suppression of plant pathogens and phosphate solubilisation. B. subtilis, a well-known biocontrol agent against major postharvest fungal pathogens of mango, such as Colletotrichum gloeosporioides [83] was detected in very low abundances on the anthoplane of the mango inflorescence $(0.06 \%)$.

The succession of endophytic Bacillus populations during fruit development appeared to be governed more by the initial composition on the inflorescence and the physiological state of the fruit [84] as opposed to environmental factors. This is evidenced by B. subtilis being present in higher abundances in both the fruit stems and stem-end pulp area at 
medium fruit size, which was then followed by a considerable decline in abundance from medium to mature fruit stage. Previously, culture-dependent methods detected B. subtilis in similar very low abundances on the mango fructoplane [3]. In fact, Wei et al. [66] reported a $50 \%$ loss of $B$. subtilis on the strawberry phyllosphere eight days after commercial biocontrol applications as a result of wash-off by rainfall. This provides a possible explanation for the decline in the abundances observed from the medium to mature stage in the current study as $10-25 \mathrm{~mm}$ of rain was experienced on the trial field during this period (Table 1). It was further suggested that in order to maintain an active population on the phyllosphere biocontrol agents, such as $B$. subtilis must be applied frequently [85].

However, the use of prochloraz as a commercial post-harvest treatment seemed to have a potential negative impact on the natural populations of $B$. subtilis at the post-harvest stage. The effect was more pronounced and persistent on the fructoplane as opposed to the stem-end pulp. This is an important finding that can be exploited for awareness on fruit biocontrol application schedules.

\subsection{Conclusions}

This study provides an indication of the baseline yet fundamental composition and dynamics of the fungal and bacterial community present on mango inflorescence, fruit stems and fruit (fructoplane and stem-end pulp area) during growth and production in a commercial orchard. Although it is not definitive from the limited dataset, the differences in the fungal and bacterial community compositions at the pre- and post-harvest stages observed were suggested to be mainly due to the stage of fruit development and responses to physical and chemical interventions. For instance, most of the families including Aspergillaceae, Aureobasidiaceae, Pleosporaceae, Cladosporiaceae and Botryosphaeriaceae declined following prochloraz dip treatment. Despite the observed differences in the microbiome, several shared taxa persist in the mango fructoplane and endosphere. Some of the major pathogenic fungal (Penicillium, Alternaria, Botryosphaeria, and Fusarium) and beneficial bacterial (Bacillus) groups observed were previously reported in several fruits including avocado and grapes. Interestingly, pathogenic fungi such as P. commune and $M$. racemosus that were previously undocumented as mango endophytes were detected pre-harvest and persisted during storage up to the ripe and ready-to-eat stage. The next step in fungal pathogen research should focus on assessing the pathogenic potential of such organisms prevalent in mango fruit. The use of fungicides seemed to reduce the diversity and abundance of some pathogenic fungal populations at the post-harvest stage though the effects did not persist to the final ready-to-eat stage. Unexpectedly, a decline in the presence of B. subtilis was observed following the prochloraz treatment which insinuated a non-target effect of the fungicide. Future studies could specifically focus on an in-depth analysis of the non-target effect of both copper fungicides during spray intervals as well as post-harvest prochloraz dip treatment and the effect they have on beneficial bacteria. This primary survey study provides first-hand essential knowledge on the impact of preharvest bacterial biocontrol applications on the overall microbial ecology and stem-end rot pathogens in mangoes during production and at the post-harvest stages. In the future, analysis such as these could lead to improved fruit microbiome-based orchard management and preventative strategies for post-harvest decay, wastes and losses.

Supplementary Materials: The following are available online at https:/ / www.mdpi.com/article/10 $.3390 /$ horticulturae7110495/s1, Figure S1: Taxonomic abundance of pathogenic fungal species at the preharvest (A) and postharvest stages (B) on the fructoplane, stem-end pulp and fruit stems of cv. Tommy Atkins mangoes. FP, fructoplane; SEP, stem-end pulp; S, fruit stem.

Author Contributions: Conceptualization, M.B. and L.K.; methodology, M.B. and L.K.; software, M.B. and L.C.; validation, J.K.G., L.C. and L.K.; formal analysis, M.B. and L.C.; investigation, M.B.; resources, L.C.; data curation, M.B.; writing-original draft preparation, M.B.; writing-review and editing, J.K.G., L.C. and L.K.; visualization, M.B.; supervision, L.K.; project administration, L.K.; funding acquisition, L.K. All authors have read and agreed to the published version of the manuscript. 
Funding: This research received no external funding.

Institutional Review Board Statement: Not applicable.

Informed Consent Statement: Not applicable.

Data Availability Statement: Publicly available datasets were analyzed in this study. This data can be found here: [https://www.ncbi.nlm.nih.gov/sra/?term=PRJNA770748].

Acknowledgments: We would like to thank ZZ2 for their assistance in providing access to the orchards and support personnel to carry out the trial.

Conflicts of Interest: The authors declare no conflict of interest.

\section{References}

1. Pal, R.K. Ripening and rheological properties of mango as influenced by ethereal and carbide. J. Food Sci. Technol. 1998, 35, 358-360.

2. Dick, E.; Adopo, A.N.; Camara, B.; Moudioh, E. Influence of maturity stage of mango at harvest on its ripening quality. Fruits 2009, 64, 13-18. [CrossRef]

3. De Jager, E.S.; Wehner, F.C.; Korsten, L. Microbial ecology of mando phylloplane. Microb. Ecol. 2001, 42, 201-207. [CrossRef] [PubMed]

4. Compant, S.; Samad, A.; Faist, H.; Sessitsch, A. A review on the plant microbiome: Ecology, functions, and emerging trends in microbial application. J. Adv. Res. 2019, 19, 29-37. [CrossRef] [PubMed]

5. Carmichael, P.C.; Siyoum, N.; Chidamba, L.; Korsten, L. Characterization of fungal communities of developmental stages in table grape grown in the northern region of South Africa. J. Appl. Microbiol. 2017, 123, 1251-1262. [CrossRef] [PubMed]

6. Lindow, S.E.; Brandl, M.T. Microbiology of the phyllosphere. Appl. Environ. Microbiol. 2003, 69, 1875-1883. [CrossRef] [PubMed]

7. Dukare, A.S.; Paul, S.; Nambi, V.E.; Gupta, R.K.; Singh, R.; Sharma, K.; Vishwakarma, R.K. Explotation of microbial antagonists for the control postharvest diseases of fruits: A review. Crit. Rev. Food Sci. Nutr. 2019, 59, 1498-1513. [CrossRef] [PubMed]

8. Perazzolli, M.; Antonielli, L.; Storari, M.; Puopolo, G.; Pancher, M.; Giovannini, O.; Pindo, M.; Pertot, I. Resilience of the natural phyllosphere microbiota of the grapevine to chemical and biological pesticides. Appl. Environ. Microbiol. 2014, 80, 3585-3596. [CrossRef]

9. Sébastien, M.; Margarita, M.; Haissam, J.M. Biocontrol in the microbiome era: Challenges and opportunities. Biol. Control 2019, 89, 98-108.

10. Blakeman, J.P. Ecological succession of leaf surface microorganisms in relation to biological control. In Biological Control on the Phylloplane; Windels, C.E., Lindow, S., Eds.; APS Press: New York, NY, USA, 1985; pp. 6-30.

11. Stefani, F.O.; Bell, T.H.; Marchand, C.; de la Providencia, I.E.; El Yassimi, A.; St-Arnaud, M. Culture-dependent and -independent methods capture different microbial community fractions in hydrocarbon-contaminated soils. PLoS ONE 2015, 10, e0128272. [CrossRef]

12. Chalupowicz, L.; Dombrovsky, A.; Gaba, V.; Luria, N.; Reuven, M.; Beerman, A.; Lachman, O.; Dror, O.; Nissan, G.; ManulisSasson, S. Diagnosis of plant diseases using the nanopore sequencing platform. Plant Pathol. 2019, 68, 229-238. [CrossRef]

13. Takushi, T.; Arasaki, C.; Ajitomi, A.; Ooshiro, A. Stem-end rot of mango caused by Diaporthe pseudophoenicicola and Neofusicoccum paroum. Jpn. J. Phytopathol. 2016, 82, 81.

14. Galsurker, O.; Diskin, S.; Maurer, D.; Feygenberg, O.; Alkan, N. Fruit stem-end Rot. Horticulturae 2018, 4, 50. [CrossRef]

15. Li, L.; Mohd, M.H.; Mohamed Nor, N.M.I.; Subramaniam, S.; Latiffah, Z. Identification of Botryosphaeriaceae associated with stem-end rot of mango (Mangifera indica L.) in Malaysia. J. Appl. Microbiol. 2020, 130, 1273-1284. [CrossRef] [PubMed]

16. Alemu, K. Dynamics and management of major postharvest fungal diseases of mango fruits. J. Biol. Agric. Healthc. 2014, 4, 13-21.

17. Giblin, F.R.; Tan, Y.P.; Mitchell, R.; Coates, L.M.; Irwin, J.A.G.; Shivas, R.G. Colletotrichum species associated with pre-and postharvest diseases of avocado and mango in eastern Australia. Australas. Plant Pathol. 2018, 47, 269-276. [CrossRef]

18. Dembele, D.D.; Amari, L.N.; Camara, B.; Grechi, I.; Rey, J.; Kone, D.M. Pre and postharvest assessment of mango anthracnose incidence and severity in the north of Côte d'Ivoire. Int. J. Biol. Chem. 2020, 13, 2714-2725. [CrossRef]

19. Kodituwakku, T.D.; Abeywickrama, K.; Karunanayake, K.O.L.C. Pathogenicity of stem-end rot associated fungi isolated from Karthakolomban mango and their control by spray and fumigation treatments with selected essential oils. J. Agric. Sci. 2020, 15, 19-36. [CrossRef]

20. Ajitomi, A.; Minoshima, A.; Takushi, T.; Truong, H.H.; Ooshiro, A.; Yamashiro, M.; Arasaki, C.; Hirooka, Y. First report of mango (Mangifera indica) stem-end rot caused by two Diaporthe species and their susceptibility to procymidone. J. Gen. Plant Pathol. 2020, 86, 237-244. [CrossRef]

21. Tovar-Pedraza, J.M.; Mora-Aguilera, J.A.; Nava-Díaz, C.; Lima, N.B.; Michereff, S.J.; Sandoval-Islas, J.S.; Câmara, M.P.S.; TélizOrtiz, D.; Leyva-Mir, S.G. Distribution and pathogenicity of Colletotrichum species associated with mango anthracnose in Mexico. Plant Dis. 2020, 104, 137-146. [CrossRef]

22. Johnson, G.I.; Cooke, A.W.; Mead, A.J.; Wells, I.A. Stem end rot of mango in australia: Causes and control. Acta Hortic. 1991, 291, 288-295. [CrossRef] 
23. Peterson, R.A.; Johnson, G.I.; Schipke, L.G.; Cooke, A.W. Chemical control of stem end rot in mango. Acta Hortic. 1991, 291, 304-311. [CrossRef]

24. Diskin, S.; Sharir, T.; Feygenberg, O.; Maurer, D.; Alkan, N. Fludioxonil-A potential alternative for postharvest disease control in mango fruit. Crop Prot. 2019, 124, 104855. [CrossRef]

25. Galsurker, O.; Diskin, S.; Duanis-Assaf, D.; Doron-Faigenboim, A.; Maurer, D.; Feygenberg, O.; Alkan, N. Harvesting mango fruit with a short stem-end altered endophytic microbiome and reduce stem-end rot. Microorganisms 2020, 8, 558. [CrossRef]

26. Govender, V.; Korsten, L. Evaluations of different formulations of Bacillus licheniformis in mango pack house trials. Biol. Control 2006, 37, 237-242. [CrossRef]

27. Senghor, A.L.; Liang, W.J.; Ho, W.C. Integrated control of Colletotrichum gloeosporioides on mango fruit in Taiwan by the combination of Bacillus subtilis and fruit bagging. Biocontrol Sci. Technol. 2007, 17, 865-870. [CrossRef]

28. Kefialew, Y.; Ayalew, A. Postharvest biological control of anthracnose (Colletotrichum gloeosporioides) on mango (Mangifera indica). Postharvest Biol. Technol. 2008, 50, 8-11. [CrossRef]

29. Ortega Morales, B.O.; Ortega Morales, F.N.; Lara-Reyna, J.; De la Rosa-Garcia, S.C.; Martinez-Hernández, A.; Jorge Montero, M. Antagonism of Bacillus spp. Isolated from marine biofilms against terrestrial phytopathogenic fungi. Mar. Biotechnol. 2009, 11, 375-383. [CrossRef]

30. Bautista-Rosales, P.U.; Calderon-Santoyo, M.; Servín-Villegas, R.; Ochoa-Alverez, N.A.; Ragazzo-Sánchez, J.A. Action mechanisms of the yeast Meyerozyma caribbica for the control of the phytopathogen Colletotrichum gloeosporioides in mangoes. Biol. Control 2013, 65, 293-301. [CrossRef]

31. Akem, C.; MacManus, G.; Dann, L.; Coates, L.; Cooke, T.; Lakhesar, D. The use of plant activators in mango postharvest diseases management. Acta Hortic. 2013, 992, 369-375. [CrossRef]

32. Terao, D.; Nechet, K.D.L.; Frighetto, R.T.S.; Anjos, V.D.D.A.; Benato, E.A.; Halfeld-Vieira, B.D.A. Physical postharvest treatments in the control of stem-end rot of mango. J. Phytopathol. 2018, 166, 581-589. [CrossRef]

33. Diskin, S.; Feygenberg, O.; Maurer, D.; Droby, S.; Prusky, D.; Alkan, N. Microbiome alterations are correlated with occurrence of postharvest stem-end rot in mango fruit. Phytobiomes 2017, 1, 117-127. [CrossRef]

34. Woolf, A.B.; Requejo-Tapia, C.; Cox, K.A.; Jackman, R.C. 1-MCP reduces physiological storage disorders of 'Hass' avocados. Postharvest Biol. Technol. 2005, 35, 43-60. [CrossRef]

35. Nisansala, Y.M.C.; Jayakody, L.K.R.R.; Sarananda, H.A.; Somaratne, S. Effect of pre-harvest potassium treatment on stem-end rot disease development of mango (Mangifera indica L.) cv. TomEJC during fruit ripening. Sabaragamuwa Univ. J. 2015, 14, 119-132. [CrossRef]

36. Montesinos-Herrero, C.; del Río, M.A.; Pastor, C.; Brunetti, O.; Palou, L. Evalua-tion of brief potassium sorbate dips to control postharvest Penicillium decay onmajor citrus species and cultivars. Postharvest Biol. Technol. 2009, 52, 117-125. [CrossRef]

37. Gomba, A.; Chidamba, L.; Korsten, L. Prevalence and serovar diversity of Salmonella spp. in primary horticultural fruit production environments. Food Control 2016, 69, 13-19. [CrossRef]

38. Weisburg, W.G.; Barns, S.M.; Pelletier, D.A.; Lane, D.J. 16 S ribosomal DNA amplification for phylogenetic study. J. Bacteriol. 1991, 173, 697-703. [CrossRef]

39. Muyzer, G.; de Waal, E.C.; Uitterlinden, A.G. Profiling of complex microbial populations be denaturing gradient gel electrophoresis analysis lof polymerase chain reaction-amplified genes coding for 16S rRNA. Appl. Environ. Microbiol. 1993, 59, 695-700. [CrossRef]

40. Porras-Alfaro, A.; Bayman, P. Hidden fungi, emergentproperties: Endophytes and microbiomes. Annu. Rev. Phytopathol. 2011, 49, 291-315. [CrossRef]

41. Gu, J.; Zhou, Z.; Li, Z.; Chen, Y.; Wang, Z.; Zhang, H. Rice (Oryza sativa L.) with reduced chlorophyll content exhibit higher photosynthetic rate and efficiency, improved canopy light distribution, and greater yields than normally pigmented plants. Field Crop Res. 2017, 200, 58-70. [CrossRef]

42. Edgar, R.C. Search and clustering orders of magnitude faster than BLAST. Bioinformatics 2010, 26, 24602461. [CrossRef]

43. Dhariwal, A.; Chong, J.; Habib, S.; King, I.L.; Agellon, L.B.; Xia, J. MicrobiomeAnalyst: A web-based tool for comprehensive statistical, visual and meta-analysis of microbiome data. Nucleic Acids Res. 2017, 45, W108-W188. [CrossRef] [PubMed]

44. Chong, J.; Liu, P.; Zhou, G.; Xia, J. MicrobiomeAnalyst for comprehensive statistical, functional, and meta-analysis of microbiome data. Nat. Protoc. 2020, 15, 799-821. [CrossRef] [PubMed]

45. Kim, B.-R.; Shin, J.; Guevarra, R.B.; Lee, J.H.; Kim, D.W.; Seol, K.-H.; Lee, J.-H.; Kim, H.B.; Isaacson, R.E. Deciphering diversity indices for a better understanding of microbial communities. J. Microbiol. Biotechnol. 2017, 27, 2089-2093. [CrossRef]

46. Aleklett, K.; Hart, M.; Shade, A. The microbial ecology of flowers: An emerging frontier in phyllosphere research. Botany 2014, 92, 253-266. [CrossRef]

47. Ottesen, A.R.; Gonzalez Pena, A.; White, J.R.; Pettengill, J.B.; Li, C.; Allard, S.; Rideout, S.; Allard, M.; Hill, T.; Evans, P. Baseline survey of the anatomical microbial ecology of an important food plant: Solanum lycopersicum (tomato). BMC Microbiol. 2013, 13, 114. [CrossRef]

48. Pusey, P.L.; Stockwell, V.O.; Mozzola, M. Epiphytic bacteria and yeast on apple blossoms and their potential as antagonists of Erwinia amylovorai. Phytopathology 2009, 99, 571-581. [CrossRef]

49. De Vega, C.; Herrera, C.M. Relationships among nectar-dwelling yeasts, flowers and ants: Patterns and incidence on nectar traits. OIKOS 2012, 121, 1878-1888. [CrossRef] 
50. Carmicheal, P.C.; Siyoum, N.; Chidamba, L.; Korsten, L. Exploring the microbial communities associated with Botrytis cinerea during berry development in table grape with emphasis on potential biocontrol yeasts. Eur. J. Plant Pathol. 2019, 154, 919-930. [CrossRef]

51. Shade, A.; McManus, P.S.; Handelsman, J. Unexpected diversity during community succession in the apple flower microbiome. mBio 2013, 4, e00602-12. [CrossRef]

52. Quintana, E.G.; Nanthacai, P.; Hiranpradit, P.; Mendoza, D.B.; Ketsa, S. Changes in mango during growth and maturation. In Mango: Fruit Development, Postharvest Physiology and Marketing in ASEAN; Mendoza, D.B., Wills, R.B.H., Eds.; ASEAN Food Handling Bureau: Kuala Lumpur, Malaysia, 1984; pp. 21-38.

53. Shen, Y.; Nie, J.; Li, Z.; Li, H.; Wu, Y.; Yafeng Dong, Y.; Zhang, J. Differentiated surface fungal communities at point of harvest on apple fruits from rural and peri-urban orchards. Sci. Rep. 2018, 8, 2165. [CrossRef] [PubMed]

54. Vadkertiová, R.; Molnarova, J.; Vranova, D.; Slavokova, E. Yeasts and yeast-like organisms associated with fruits and blossoms of different fruit trees. Can. J. Microbiol. 2012, 58, 1344-1352. [CrossRef]

55. Martinson, E.O.; Herre, E.A.; Machado, C.A.; Arnold, A.E. Culture-free survey reveals diverse and distinctive fungal comminities associated with developing figs (Ficus spp.) in Panama. Microb. Ecol. 2012, 64, 1072-1084. [CrossRef]

56. Shiea, C.; Huang, Y.L.; Liu, D.L.; Chou, C.C.; Chou, J.H.; Chen, P.Y.; Shiea, J.; Huang, M.Z. Rapid screening of residual pesticides on fruits and vegetables using thermal desorption electrospray ionization mass spectrometry. Rapid Commun. Mass Spectrom. 2015, 29, 163-170. [CrossRef] [PubMed]

57. Vionnet, L.; De Vrieze, M.; Agnés, D.; Gfeller, A.; Luthi, A.; Haridon, F.L.; Weisskopf, L. Microbial life in the grapevine: What can we expect from the leaf microbiome? OENO One 2018, 52, 219-224. [CrossRef]

58. Postmaster, A.; Sivasithamparam, K.; Turner, D.W. Enumeration and identity of microorganisms isolated from te surface of banana fruits at three developmental stages. Sci. Hortic. 1997, 69, 189-197. [CrossRef]

59. Lindow, S.E.; Andersen, G.L. Influence of immigration on epiphytic bacterial populations on navel orange leaves. Appl. Environ. Microbiol. 1996, 62, 2978-2987. [CrossRef] [PubMed]

60. Alkan, N.; Fortes, A.M. Insights into molecular and metabolic events associated with fruit response to post-harvest fungal pathogens. Front. Plant Sci. 2015, 6, 889. [CrossRef] [PubMed]

61. Du Plooy, G.W. Aspects of Mango (Mangifera indica L.) Fruit Rind Morphology and Chemistry and Their Implication for Postharvest Quality. Ph.D. Thesis, University of Pretoria, Pretoria, South Africa, 2006.

62. Abdelfattah, A.; Wisniewski, M.; Li Destri Nicosia, M.G.; Cacciola, S.O.; Schena, L. Metagenomic analysis of fungal diversity on strawberry plants and the effect of management practices on the fungal community structure of aerial organs. PLoS ONE 2016, 11, e0160470. [CrossRef] [PubMed]

63. Stirling, A.M.; Pegg, K.; Hayward, A.C.; Stirling, G.R. Effect of copper fungicide on Colletotrichum gloeosporioides and other microorganisms on avocado leaves and fruit. Aust. J. Agric. Res. 1999, 50, 1459-1468. [CrossRef]

64. Lonsdale, J.; Kotze, J. Chemical control of mango blossom diseases and the effect on fruit set and yield. Plant Dis. 1993, 77, 558. [CrossRef]

65. Eilenberg, J.; Hokkanen, H.M.T. An Ecological and Societal Approach to Biological Control; Springer: Dordrecht, The Netherlands, 2007.

66. Danderson, M. Omega* (Prochloraz), a fungicide for post-harvest control of anthracnose, the dothiorella/colletotrichum complex and stem-end rot in avocados. S. Afr. Avocado Grow. Assoc. Yearb. 1986, 9, $27-30$.

67. Sudheer, K.P.; Chandra, P.; Gajbhiye, V.T.; Kumar, R. Uptake of benomyl fungicide from postharvest treatment and its persistance in modified atmosphere stored banana fruits. In Occupational Safety, Health E Environment and Sustainable Economic Development; Chaturvedi, P., Ed.; Concept Pubishing Company: New Delhi, India, 2007; pp. 31-36.

68. Lievens, B.; Hallsworth, J.E.; Pozo, M.I.; Belgacem, Z.B.; Stevenson, A.; Willems, K.A.; Jacquemyn, H. Microbiology of sugar-rich environments: Diversity, ecology and system constraints. Environ. Microbiol. 2015, 17, 278-298. [CrossRef]

69. Johnson, G.I.; Kotzé, J.M. Stem-end rot. In Compendium of Tropical Fruit Diseases; Ploetz, R.C., Zentmyer, G.A., Nishijima, W.T., Rohrbach, K.G., Ohr, H.D., Eds.; APS Press: St Paul, MN, USA, 1994; pp. 81-83.

70. Mphahlele, M.P. Honey-Bee Dissemination of Bacillus subtilis to Citrus Flowers for Control of Alternaria. Master's Thesis, University of Pretoria, Pretoria, South Africa, 2001.

71. Prakash, O.M.; Misra, A.K. Diseases of mango and their management. In Diseases of Fruits and Vegetables and Their Management; Thind, T.S., Ed.; Kalyani Publishers: Ludhiana, India, 2001; pp. 47-72.

72. Nayak, G.; Altekar, N. Effect of biofield treatment on plant growth and adaptation. J. Environ. Health Sci. 2015, 1, 1-9.

73. Hakizimana, J.D.; Gryzenhout, M.; Coutinho, T.A.; van den Berg, N. Endophytic diversity in Persea americana (avocado) trees and their ability to display bicontrol activity against Phytophtora cinnamomi. In Proceedings of the VII World Avocado Congress 2011, Cairns, Australia, 5-9 September 2011.

74. Sanderson, P.G.; Spotts, R.A. Postharvest decay of winter pear and apple fruit caused by species of Penicillium. Phytopathology 1995, 85, 103-110. [CrossRef]

75. Louw, J.P.; Korsten, L. Pathogenic Penicillium spp. on apple and pear. Plant Dis. 2014, 98, 590-598. [CrossRef]

76. Kwon, J.-H.; Hong, S.-B. Soft rot of tomato caused by Mucor racemosus in Korea. Mycobiology 2005, 33, 240-242. [CrossRef]

77. Saito, S.; Michhailides, T.J.; Xiao, C.L. (Mucor rot- An emerging postharvest disease of mandarin fruit caused by Mucor piriformis and other Mucor spp. in Califonia. Plant Dis. 2016, 100, 1054-1063. [CrossRef] 
78. Phillips, A.J.L.; Alves, A.; Abdollahzadeh, J.; Slippers, B.; Wingfield, M.J.; Groenewald, J.Z.; Crous, P.W. The Botryosphaeriaceae: Genera and species known from culture. Stud. Mycol. 2013, 76, 51-167. [CrossRef]

79. Johnson, G.I.; Gosbee, M.J.; Joyce, D.C.; Irwin, J.A.G. Control of stem-end rot in mangoes. In Proceedings Mango 2000 Marketing Seminar and Production Workshop, Townsvile, QLD; Department of Primary Industries Queensland Conference and Workshop Series QC95006: Townsville, Australia, 1995; pp. 223-229.

80. Prusky, D.; Kobiler, I.; Miyara, L.; Alkan, N. Fruit diseseses. In The Mango: Botany, Production and Uses; Litz, R., Ed.; CABI International: Wallingford, UK, 2009.

81. Louw, J.P. Pathogenicity and Host Specificity of Penicillium spp. on Pome and Citrus Fruit. Master's Thesis, University of Pretoria, Pretoria, South Africa, 2014.

82. Mandic-Mulec, I.; Stefanic, P.; van Elsas, J.D. Ecology of Bacillaceae. Microbiol. Spectr. 2015, 3, 1-24. [CrossRef]

83. Korsten, L.; De Villiers, E.E.; Wehner, F.C.; Kotzé, J.M. Field sprays of Bacillus subtilis and fungicides for control of preharvest fruit diseases of avocado in South Africa. Plant Dis. 1997, 81, 455-459. [CrossRef] [PubMed]

84. Khare, E.; Mishra, J.; Arora, N.K. Multifaceted interactions between endophytes and plant, developments and prospects. Front. Microbiol. 2018, 9, 2732. [CrossRef] [PubMed]

85. Wei, F.; Hu, X.; Xu, X. Dispersal of Bacillus subtilis and its effect on strawberry phyllosphere microbiota under open field and protection conditions. Sci. Rep. 2016, 6, 22611. [CrossRef] [PubMed] 